\title{
OBITUARIES
}

\section{Dr. Annie J. Cannon}

$\mathrm{A}^{\mathrm{N}}$ NNIE JUMP CANNON, who died on April 13, was born at Dover, Delaware, on December 11, 1863. While still a very little girl her curiosity was attracted towards the stars ; and many evening hours were spent with her mother learning the constellations. When she left school, her father, despite the prejudice in those days against the university training of girls, sent her to Wellesley College where she graduated B.S. in 1884. Later she returned to Wellesley as a graduate student and studied physics under Prof. Sarah F. Whiting. After specializing in astronomy for two years at Radcliffe College she was appointed an assistant at the Harvard College Observatory under the inspiring directorship of E. C. Pickering. It was natural that here her interests should have become focused on variable stars and on the study of stellar spectra, the subject which was to become the great work of her life. In 1911 Miss Cannon was made curator of astronomical photographs at Harvard, and in 1938 was appointed William Cranch Bond astronomer, a post created in honour of the first director of the observatory. Though she officially retired from the staff of the Observatory in the summer of 1940 , she continued with active work in her old department until a few weeks before her death.

Miss Cannon received many academic honours. Honorary degrees were conferred upon her by the University of Delaware, her own State; by the University of Groningen, Holland; by Wellesley, her Alma Mater; by Oxford, by which university she was the first woman to be honoured with a doctor's degree ; by Oglethorpe University; and by Mount Holyoke College. In 1931 she was awarded the Draper Medal of the National Academy of Sciences, and in 1932 the Ellen Richards Prize. In 1914 she was elected an honorary member of the Royal Astronomical Society.

Although much the greater part of Miss Cannon's work consisted in the study of astronomical photo. graphs and in the compilation of her own and other people's results, she was herself a very able observer. She made regular visual observations of variable stars, especially during the early years at Harvard; and many of the photographs used in her investigations were taken by herself. In 1922 she spent six months at the Harvard station at Arequipa, Peru, photographing the spectra of the southern stars with the 10-in. Metcalf telescope. Her work on variable stars alone was very prolific. She was one of the pioneers in the photographic study of stellar variability. She discovered 277 variable stars and 5 new stars, and published several extensive catalogues of variable stars. Perhaps her most important contribution to this branch of astronomy was her compilation of a bibliography of variable stars comprising more than half a million separate cards, which she always kept up to date, and which has been of immeasurable value to all workers in this field.

By far her most important work was the production of the "Henry Draper Catalogue", which in nine volumes of the Harvard Annals gives the spectral types and magnitudes of 225,300 stars completely over the whole sky down to about the ninth magnitude. Not only was Miss Cannon responsible for the examination and classification of the spectra and for the preparation of the material for publication, but it was mainly due to her that the system of classification adopted in the catalogue was developed and ultim. ately defined. The classification was first described by her in 1900, and again, with slight modifications, in 1912 ; most of the work of classifying the spectra was carried out between 1911 and 1915 ; the first volume of the catalogue was published in 1918 ; and the ninth and last volume was published in 1924 . It was in 1922 that this same system of classification was adopted by the International Astronomical Union as the official system for the classification of stellar spectra. Since the publication of the main catalogue Miss Cannon had been working on its extension to fainter stars, down to about the 1lth magnitude, in the Milky Way and other special regions. She was occupied with this work up to the time of her last illness ; and already one volume of the "Extension" had been published.

Miss Cannon did much to further the study of science among women; and in 1933 she founded the Annie J. Cannon Prize to be awarded every few years to some outstanding woman astronomer. But there are other reasons why women of science are indobted to Miss Cannon; for through her lectures, through the example of her own work and enthusiasm, and through the help and encouragement which she so freely bestowed, she was an inspiration to all whom she came across.

Miss Cannon was not only one of the greatest of women astronomers, she was also a woman with a great personality and wide interests, yet withal she was one of the kindest, simplest and happiest of women. She had friends all the world over, among the highest and the humblest, among the oldest and the youngest; and when she was at home surrounded by her work she was never too busy to welcome them. In the death of Annie J. Cannon astronomy has lost one of its most valued workers and countless people a devoted friend.

R. L. WATERFIELD.

\section{Prof. Edmond Leplae}

News has just reached Great Britain of the death of Prof. Edmond Leplae, professor of agriculture in the University of Louvain, and director-general at the Belgian Ministry for the Colonies, which took place at Louvain on February 2. $\mathrm{He}$ had been 
staying with his daughter and son-in-law in England not long before the War, but unfortunately returned to Belgium and, when the German invasion occurred, he and his wife fled to France, without being able to reach Great Britain; after the collapse of France they returned to Louvain. It was the second time he had been made homeless by the Germans, but in the War of 1914-18 he had been able to get to Britain and continue his work.

$\mathrm{He}$ studied at Louvain, and after making agricultural journeys in North Africa and Brazil, he returned there in 1901 to initiate a course in tropical agriculture. In 1910 the Belgian Government recognized the necessi!y for developing the agriculture of the Belgian Congo and appointed him director-general. He visited on a study mission the Dutch Indies and the British tropical Empire, and used the experience thus gained in organizing the agriculture of the Congo. It was necessary to provide schemes covering the needs of both Belgian colonists and native cultivators. One of the features which was being watched with interest was the introduction of certain compulsory crops into the native agriculture for the benefit of the native.

Prof. Leplae was one of the leading Continental authorities on tropical agriculture, and his papers issued by the Belgian Ministry include some of the best published on the Belgian Congo. He became favourably known in Great Britain as the result of a report of an agricultural journey in the Congo showing the marked progress that had been made since the Belgian Government had taken over the country in 1908. Native agriculture had been much developed by the extension of rice, oil palm, cotton, rubber and other crops, and although few Belgians had gone out as planters, the living conditions had been so improved as to make possible a considerable extension of plantation industry. A Botanic Garden and Experiment Station had been established at Eala on the equator, and there were other experimental farms in other parts of the country, among them, at Api, a station for the study and the rearing of elephants.

Prof. Leplae's special interests were the conservation of the soil and the development of livestock. He published several important papers on the latter subject and did pioneering work on the conditions necessary for the healthy growth of the animals. The best known is his long report "Organisation et exploitation d'un élevage au Congo Belge", the first edition of which was published in 1926 and the second in 1933 ; this dealt mainly with cattle; a later report dealt with sheep.

Others of his papers dealt with coffee and with quinine; he early realized the danger of allowing the Congo to become too dependent on the Dutch Indies and advocated a wider culture of cinchona in the Congo.

Leplae will long be remembered both for his contributions to scientific agriculture and for his charming personality. He was an ideal president of an international gathering; at one of the last of these kefore the War, the Congress of Tropical and
Sub-Tropical Agriculture, held at Tripoli in March 1939, he presided with great distinction, and, in spite of the strained situation and the haunting fear at the back of everyone's mind, he carried the meeting through with complete success. He had a perfect command of English, and understood well and deeply sympathized with English ideals without abating in any way his profound affection for his own country.

\section{E. J. Russell.}

\section{Dr. R. P. Hobson}

By the death of Dr. R. P. Hobson at Bangor on April 12 at the early age of thirty-nine, agricultural science and biochemistry have lost a very able research worker. Dr. Hobson came to Bangor in 1934 to work on the sheep maggot problem in co-operation with the late Dr. Maldwyn Davies. His previous researches at Rothamsted and the London School of Tropical Medicine fitted him admirably for this work, funds for which were provided by the Agricultural Research Council. His publications dealing with this subject included ten studies (two in the Press) in the Annals of Applied Biology, and, in addition, contributions were made to the Biochemical Journal, Nature and Agriculture.

The advances Hobson made in these studies are of fundamental importance, and his technique for attracting flies to oviposit on sheep, developed from a study of the chemotropism of the flies and the chemistry of the fleece, has been universally adopted. Workers in Australia, where sheep maggot research has proceeded for much longer and on a much bigger scale than in Great Britain, held Dr. Hobson's work in high esteem, and I know that they will regard their loss as being as great as ours. His more recent work on the effect of suint on sheep dips and the toxicity of calomel to blow-fly eggs is of far-reaching importance. Proposals for developing the ecological side of blow-fly investigations are being examined by the Agricultural Research Council. It was intended that this ecological work should run parallel with Dr. Hobson's researches, and his death at the present juncture is an incalculable loss.

Although not physically strong, Dr. Hobson's health improved after coming to Bangor, and his death after undergoing a major operation came as a great shock to all his friends. His colleagues at the School of Agriculture have suffered a grievous loss, and they offer their deepest sympathy to his widow, who is a member of the same staff. I. Thомas.

\section{WE regret to announce the following deaths:}

Mr. John Crompton, O.B.E., former president of the Textile Institute, Manchester, on May 31, ag€d seventy-eight years.

Mr. R. L. Hobson, C.B., keeper until 1938 of the Department of Oriental Antiquities and of Ethnography in the British Museum, on June 5, aged sixty-eight.

Admiral Sir Frederick Learmonth, K.B.E., C.B., hydrographer of the Navy during 1919-24, on June 3 , aged seventy-five. 